\title{
Cleaner of Windows, Taker of Journeys: Rereading Jane Jacobs
}

In recent years a number of books have appeared that testify to the great power of Jane Jacobs' work: Robert Fulford's The Accidental City does a dandy job of showing her ideas and presence at work in Toronto's renaissance; James C. Scott's Seeing Like a State, subtitled "How Certain Schemes to Improve the Human Condition Have Failed," pits The Death and Life of Great American Cities against the "High Modernist City" most famously associated with Le Corbusier; Ideas that Matter: The Worlds of Jane Jacobs is a collection of her words and those of admirers (especially) and naysayers (more briefly) edited by Max Allen. This latter found a good deal of its material in the Jane Jacobs Archives at Boston College. This is not, thus, someone the world does not know.

Nonetheless, there is reason to regret at least some of the ways she is known, even some of the ways she has been admired. I sense two gaps here, and they are perhaps equally wide. One is between those people - I have no way of knowing how many they are, except that I am one - for whom Jacobs' books have become a major and irreplaceable way of seeing and understanding the world around them, and those who, when they say they have "read Jane Jacobs" mean essentially that they have read Death and Life of Great American Cities, and primarily "as an attack on current city planning and rebuilding." The second is between these admirers of whatever sort and those who have read something by Jacobs and have found it unconvincing, wrongheaded, sloppy, incomplete, something to trivialize or dismiss.

The offer Jacobs makes, in prose any smart high school senior can understand, with a modest but confident manner that could not strike anyone as arrogant or elitist, is to wash our windows so we can see and understand clearly - not just our cities, though these are the centers of her attention, but all that surrounds them, suburban, rural, national, multinational. Why have so many been content - Gap 1, as I see it - to know her for her devastating assaults on an urban planning idea that is now, thanks to Jacobs and its own folly, almost half a century out of date? Why have so many - this is Gap 2 - simply deflected, refused, and frequently spoken as if Jacobs were the leader of some cult?

Fulford is the first writer of my acquaintance who pointed out that Death and Life of Great American Cities is one of a cluster of books published in the early 1960s, all written by nonprofessionals, about crises brought about primarily by the glut of the Eisenhower years: Rachel Carson's Silent Spring, Betty Friedan's The Feminine Mystique, Paul Goodman's Growing Up Absurd, Ralph Nader's Unsafe at Any Speed. To these might be added Michael Harrington's The Other America, which got into the hands of the Kennedys and then became a driving force behind Lyndon Johnson's Great Society. 
It is an impressive array, and, with the possible exception of Goodman's, each educated a public force strong enough to do major damage to various entrenched establishments. But the very fact that each was able to do this did, I think, permanent harm to the way people think about Jacobs. Carson and Goodman died shortly after their books were published, while Nader, Friedan, and Harrington clearly had delivered their major messages with these books. Jacobs, though, is another matter.

First of all, Death and Life of Great American Cities, though it offers itself as an attack on postwar urban planning, has underlying it a profound idea concerning the "organized complexity" of urban life that, alas, is easy to ignore or else to trivialize. Jacobs herself describes the process:

A few years ago I gave a talk about the need for commercial diversity in cities.

Soon my words began coming back to me from designers, planners, and students in the form of a slogan (which I certainly did not invent): "We must leave room for the corner grocery store."

To this day many of her admirers as well as her assailants trivialize her in just this fashion. Secondly, Jacobs was just getting started with this book, and each succeeding one - The Economy of Cities, Cities and the Wealth of Nations, Systems of Survival - was written because, she felt, she had left something unor under-examined. This means that while each can be read on its own, the group of four is best read in order, not so much as the unfolding of a magnum opus as the journey of someone whose mind is eager and restless, able to build on its previous successes, and what those successes had kept her from seeing. She cleaned her own windows first.

Gap 1, then, was created by the very success of Death and Life. It came in an activist time, and it allowed admirers and detractors alike to think of Jacobs primarily as an activist, especially since, indeed, she has always been one in her local scenes in New York and Toronto. Find out what is wrong with "highmodernist" urban planning and you can claim to have learned all that Jacobs can teach you. She thereby is reduced to someone who is "for" something and "against" some other things, and that is, indeed, a great reducing.

My guess is that what I've just described is truest for people who were already adult when Death and Life was first published, which is to say, no one under fifty and few under sixty. To get at the sources of Gap 2-I will enumerate three in my next section, and two more related ones near the end I want to tell a story about some readers who not only are much younger than that but who also read Cities and the Wealth of Nations without ever having heard of its author, or ever having lived in an activist time.

One student could sense the gap, his classmates on one side, me and Cities and the Wealth of Nations on the other, and he really wanted to help.

"How do you calculate the economic value of a poet?"

I wanted to thank him. If I couldn't come up with something plausible, I could be in real trouble. "Does this make sense to you: the economic value of 
poets in Seattle rose considerably when Elliott Bay Books began its series of authors' readings in the seventies?"

The student says he is new to Seattle. Most of the others look blank.

"OK. Let's name bookstores in Seattle." Quickly we come up with a dozen or more.

"How many of these sell poems?" The number stays quite large.

"How many of these existed twenty-five years ago?" No one knows, but I have the yellow pages at hand, as I usually do while teaching Jacobs. There are well over a hundred bookstores listed, maybe thirty that might sell poems. On a quick guess, twenty-five years ago there were thirty stores, and maybe half a dozen that sold poems. We then do the same for book publishers: about a hundred, most small, certainly, but many looking as though they wouldn't refuse to publish poems. Vastly more than were around a generation ago.

"What's happened, then?" The students want to be helpful. One mentions a boom in rock music recording in Seattle, another at least a boomlet in moviemaking. When we come up with a decent sized list of theaters and dance studios, they are willing to believe these numbers too are much larger than they were a few decades ago.

So, if poets, musicians, actors, dancers, directors, and their producers are creating new work here, that means that many who once would have had to go elsewhere to ply or publish or enact their trade can stay at home, and others from elsewhere might well come because the action in the arts is burgeoning. To be sure, Seattle, like the rest of America, still imports most of its books from New York and its movies from Hollywood, but the numbers are impressive, and I am exhilarated, since we've established the idea of seeing Seattle as an importer/exporter. But when I go back to try to make this a story about what might have created this proliferation of bookstores, publishers, recording and movie studios, I soon am having to do too much of the talking, and the blank faces return. When the fun subsides, when they feel they aren't really contributing, many retreat to what is easy to say, what many of their elders find easy to say at such a moment.

Namely, this isn't really economics we're talking about; economics is about nations, Phillips curves and Laffer curves, locally it's about cuthroat operations among banks and retailers, it's about employment at Boeing. Hasn't our one Economics major said that no one knows Jacobs in the Ec department, and that what she writes about is studied, if at all, in the Geography Department, that cowbird among the soft sciences? Namely, cities are a matter of location, natural resources, culture, and while of course people work in them, they aren't really economic units. At some point in here someone is bound to announce that Jacobs is "wrong" when she writes that "Seattle has no city region to speak of" and so has been "stagnating and not pulling out of it." Who can trust a writer who makes such mistakes?

The situation I describe is one I've been in more than once. I want now to 


\section{Left History 7.1}

try to name the attitudes, and perhaps hidden assumptions that underly the need to respond thus when asked "What happened in the last generation to bring about these changes we've just been talking about?" It's quite an array, and I wouldn't pretend that every person who begins to go blank or become aggressively defensive at this moment shares them all. They range from simple habits of mind, shortcuts of the kind we all take, to some complex attitudes not easy to get at.

First, there is a tendency, once one sees that changes have taken place, to think those changes were inevitable. Thus, simply saying that the economic value of poets rose in Seattle when Elliott Bay Books began its authors' readings might qualify as something quaint, vaguely interesting, but when I ask what processes could have taken place to fuel a lot of new or previously imported work in the arts, the students really aren't interested: the changes did happen, they give the appearance of having had to happen, so why fuss the matter, especially since the processes, for them, do not much concern economics at all? Which means not only does it seem as though Microsoft, say, has always been with us, but that it was inevitable that Bill Gates would happen, and here. Thus, after "How do you calculate the economic value of a poet?" the class looked at what the Yellow Pages told us about the explosive growth in Medical Equipment and Supplies inside Seattle's city region. Again, the students liked doing this because one could describe a medical equipment firm started by her father, and another had an employer who branched off into this field. This was what helped them to hoot at Jacobs' statement that Seattle had no city region, and they found it hard to believe that something so familiar to them as high tech on Seattle's east side hadn't been written in the stars, and ages ago.

Of course everyone knows that all changes are not inevitable; what's hard to see, what's hard even to try to see, is how concurrent changes inside a city are related to each other even though it looks like they aren't, and how, roughly speaking, changes that are making a city grow are almost never inevitable, though, after a certain point in a decline in a city, further decline or stagnation may well be inevitable. It all has to do with "the kind of problem a city is," to the way economic life is related both to other economic life inside a city and to the lives of poets, the quality of activism, the attitudes and aspirations of the young in the same place. Not seeing this, not geared to look for complex patterns, it frequently is easier to settle for portents when locating change: good local businesses are being killed by megastores; there are too many new Asian restaurants; it's too expensive to live here now.

Second, it is hard for many to shake the feeling that what Jacobs does is amateurish. She never went to college, she finds a great deal of her material just by reading The New York Times, The Wall Street Journal, and books she might find in a branch of the public library. That she writes clearly is a kind of mark against her as well, since specialists, especially academic specialists, tend 
to write very badly, and the quality of their prose stands as a testament to the difficulty of their tasks. If economists do not know "cities" as a unit of contemplation, they surely must have a reason for ignoring them. Readers have been trained to think of arguments as "valid" or "invalid," and so, rather than take what Jacobs offers and go out into the world and see what one might do with it, it seems easier to look for, and therefore inevitably to find, "objections."

Third, a powerful corollary of this, has to do with method. Almost everything Jacobs writes begins with a story: the story of the imagined city of New Obsidian; the story of a maker of industrial abrasives that became the $3 \mathrm{M}$ Company, maker of Scotch tape; the story of how Japanese bicycle repair became bicycle manufacture. These examples are all in The Economy of Cities; go back to Death and Life and find the story of William Penn's four residential squares in Philadelphia, or of the potential "self-destruction of diversity" on 8th St. in New York; go ahead to The Wealth of Nations and there is the story of why the vaunted TVA project didn't work, or of how Venice grew by developing trade with cities as backward as itself.

Let the story she tells about Detroit in The Economy of Cities serve as what Kenneth Burke calls a Representative Anecdote for the opportunities and disasters inherent in most city life. After an early career as a flour miller, Detroit shifted from mill machine repair to marine manufacture:

While the engine business was growing, it was supporting a growing collection of its own suppliers: shops that made parts and tools, others that supplied metal. The most important were the refineries and smelters that supplied copper alloys made from local ores, to shops where brass valves and other bits of engine brightwork were manufactured. The refineries too began to find customers outside of Detroit, and soon they became so successful that between 1860 and 1880 copper was Detroit's largest export.

Then the copper ran out, so Detroit had to begin importing it. This was not at all an economic disaster: By 1880 Detroit had produced so many exportspaints, vamishes, steam generators, pumps, lubricating systems, tools, store fixture stoves, medicines, furniture, leather for upholstery. sporting goodsthat they soon more than compensated for the loss of refineries. The economy was becoming so diverse and interwoven that when Henry Ford started making Model Ts in 1905 he found that almost everything he needed for their manufacture could be found right there in Detroit. But after it became a major city as a manufacturer of automobiles its economy became both more efficient and less diversified so that it began to take on the look of a company town, one that knew not how to recover when it was no longer the only manufacturer of the world's cars and trucks.

It has to be told as story, a tale of possibilities created, grasped, abandoned. Why should that be a drawback? We all know story is absolutely basic to the human way of understanding, except among the guardians, especially the academic guardians, especially when the subject is something, like a city, that 
does not seem to have a story. Stories aren't susceptible to proof, stories aren't valid or invalid, stories do not seek from readers or hearers assent, demur, or denial, but imaginative cooperation. Why is "narrative history" practically synonymous with popular fiction among academic historians? Why is the "research" on stories (narratology, God help us) both very meager and almost always destructive of whatever interest stories can have? Why is "storytelling" only a branch of library science or public speaking. I can claim that in fortyodd years of teaching I have seldom had a class that was not interested in a story if I told it well, and have seldom had a class that knew how to take a story as seriously as they took "analysis," or "issues," or some such.

Jane Jacobs is not the least bit uninterested in "analysis," or "issues." She absolutely depends on being able to use her stories as the grounding for generalization. The difference between her and others is her fascination with her stories and with what they reveal about cities (and what cities reveal about us as human beings), so they are never just evidence carefully crafted to prove a point. Start with her stories, and then see the generalizations and the arguments as bridges from her particulars to our own. Jacobs does not say anything about the economic value of a poet, and I never had until asked. But I've learned that my particulars would become explorable and intelligible if I could leam to cross over the bridge. My students had to use Jacobs' idea of "city region" to quarrel with her statement that Seattle didn't have one; I had to see that when the long period of stagflation that is the context for Cities and the Wealth of Nations, came to an end, and cities like Seattle, or Cleveland, or Pittsburgh, rebounded from disaster a generation earlier, it would be Jacobs' descriptions of new city work and explosive growth from import replacement in The Economy of Cities that gave me all I needed to understand these turnarounds. If the question is why Singapore, Hong Kong, Taipei, and Seoul withstood economic earthquakes that threatened so much of Asia and sent Kuala Lumpur, Bangkok, and Jakarta reeling, then "Why Backward Cities Need Each Other" and "Faulty Feedback to Cities" in The Wealth of Nations show the way. You can even say that those cities that still imagine, after the crisis is alleviated by an IMF handout, that they can export their way to security just haven't read Jacobs carefully enough; cities that are only economic colonies of wealthier places are weak and unable to respond when trouble comes. But you need to think of cities, not countries, as the basic economic unit, and to remember that what happens in a city over time is like what happens in the life of a person: everything changes, everything connects.

Perhaps the greatest single story in all this is that of Jacobs herself as she moved from book to book. She has written me that she saw, after Death and Life was published, that she had offered no explanation for how work begins in a city neighborhood, and so she wrote The Economy of Cities to find out. I had a chance in reviewing that book to praise it highly but to point out that her concern with processes of growth and stagnation had led her to ignore the 
obvious fact that cities whose stories followed similar patterns might nonetheless be quite different from each other. She replied, Yes, of course, and whatever else Cities and the Wealth of Nations might seem to be about, it addressed that very fact.

There is nothing professional about this wonderful way of developing a career. To use a word she likes to use, she flubdubs around, trial and error, finding ways to see the truths her stories reveal so the bridge can be built and others can cross it. And many have preferred to snipe or trivialize rather than take the journey. "There is not much here," sniffs James Ring Adams in Commentary about The Wealth of Nations, "of precise definitions, or economic modeling, or statistical evidence." Because, of course, Adams' point is that Jacobs is not just an amateur but a lefty. Equally of course, Robert $F$. Wagner $\mathrm{Jr}$. in The New Republic finds Jacobs "profoundly conservative," because she is "strongly opposed to planning and ... welfare payments" and "government intervention."

The first of those sedentary types who refused the journey was Lewis Mumford who, when he realized that Jacobs was smart and strongly opposed to the Garden City tradition Mumford had come to espouse, entitled his long attack on Death and Life "Mother Jacobs' Home Remedies." The cat was probably out of the bag back then, but no one saw it: the fourth and perhaps most deep seated reason for wanting to dismiss, or perhaps condescendingly nod and dismiss, is the gender of the author. This was not, perhaps, such a telling factor with her first book, since it was evident to many by 1961 that high modern planning was a disaster, but for a woman to attempt to reorganize the study of economics, not just by making cities its focal point but by making the whole thing intelligible - that, I think, was just too much. Mumford could get away with his title because he was full of years lived inside the Feminine Mystique, but it is hard not to read most writers on her work, including many who praise her but in ways that smack of condescension, without feeling they are responding to the scent of a woman.

Nor is this just a matter of professional pique or outrage, for underlying that assumption about women and economics is its corollary the high modern conviction that cities are breeding grounds for alienation and despair - Les Fleurs de Mal, The City of Dreadful Night, The Waste Land, Charlie Chaplin in Modern Times, film noir, the mean streets, etc... - so ubiquitous that no one sees how highly gendered it is. Set against all that: Lucy Snowe coming to London in Charlotte Bronte's Villette, or Toni Morrison's account of southern blacks coming to Harlem in Jazz, or Mrs. Dalloway setting out across London to order her flowers, or Martha Quest coming to London at the opening of The Four Gated City. All these women characters and writers acknowledge the reasons for alienation and despair, the overwhelming confusion of large cities, but they know also a sense of richness, of possibility, in the very qualities the men deplore. 


\section{Left History 7.1}

Jacobs herself, for obvious reasons, has never referred to this, at least in print. But in the last great book, Systems of Survival, the sense is very strong that most of those who have never accepted any invitation, from her and perhaps from any woman when it came to considering cities, were men working in what she identifies as the guardian syndrome, men with establishments and traditions to protect. While she has no interest in engaging in a sex war, she doesn't mind, in this book, putting much of the evidence and arguments about the ethics' of traders into the mouth of Kate. So, at one moment:

"I like what C.S. Lewis said about courage," Jasper put in, "He called it the master virtue because it makes the practice of all the others possible."

"Maybe," said Kate, "but I'd think cooperation is probably the most important of the universals. We're social animals, and everything we are or have hangs upon cooperation."

(That, says my wife, reading these words, is the real point). The guardians tend to prefer courage, and leadership, to cooperation, or coming to voluntary agreements or, respect of contracts, or that commercial virtue which seems to have guided Jacobs herself the most: "Be open to inventiveness and novelty."

Take the journey. Cross over the bridge. Have one's windows cleaned. All these require a sense of cooperation and collaboration in order to work. Most traders are too busy being traders to bother with the kind of reading about themselves that Jacobs offers; it is guardians, with their different and alien syndrome of ideas and ethics who read her and, very frequently, feel her alienness in its traderly sense of things: shun force, admire honesty, seek optimism. To say these commercial virtues are gendered does not make all traders women any more than it makes all women cowards. But it does offer an explanation for the gap between this much admired and little fully understood writer and those who feel that cooperation with her is different from what they are used to, and more than they know how to give.

Roger Sale

University of Washington

Karin A. Shapiro, A New South Rebellion: The Battle Against Convict Labor in the Tennessee Coalfields, 1871-1896 (Chapel Hill: University of North Carolina Press, 1998).

To a growing literature on American convict leasing, $A$ New South Rebellion adds a bracing account of free workers organizing to repeal the lease. Along with other Southern Reconstruction states, Tennessee began leasing its overwhelmingly African American prisoners out as labourers in 1871. Coal operators rented convict miners less for a cheap labour force than for a reserve 